\title{
Factors Affecting Concentrations of Airborne Conidia of Oidium sp. Among Poinsettias in a Greenhouse
}

\author{
J. M. Byrne, Graduate Research Assistant, M. K. Hausbeck, Associate Professor, and B. D. Shaw, Former Re- \\ search Assistant, Department of Botany and Plant Pathology, Michigan State University, East Lansing 48824
}

\begin{abstract}
Byrne, J. M., Hausbeck, M. K., and Shaw, B. D. 2000. Factors affecting concentrations of airborne conidia of Oidium sp. among poinsettias in a greenhouse. Plant Dis. 84:1089-1095.

Atmospheric concentrations of Oidium sp. conidia in two research greenhouses containing infected poinsettias were monitored to investigate the role of environment in prompting conidial release and dissemination. Hourly concentrations of conidia of Oidium sp. were estimated using a Burkard volumetric spore sampler. The influence of temperature on disease development was studied by placing healthy poinsettias in each greenhouse for 7-day periods, removing them, and recording the days to the appearance of the first colony. When averaged over 5 December to 1 June, atmospheric conidial concentrations in greenhouse (GH) 2 were greatest during 1000 to 1800 hours with a peak ( 325 conidia $/ \mathrm{m}^{3} / \mathrm{h}$ ) occurring at 1200 hours. In GH 11 , peak concentrations occurred at 1300 hours $\left(65 \mathrm{conidia} / \mathrm{m}^{3} / \mathrm{h}\right)$ and 1600 hours $\left(75 \mathrm{conidia} / \mathrm{m}^{3} / \mathrm{h}\right)$. Large numbers of conidia were sampled $\left(\geq 100 / \mathrm{m}^{3}\right)$ within 1-h periods, indicating conidial release events (CREs). Fluctuations in relative humidity (RH) (either positive or negative) prompted CREs. In both greenhouses, the highest number of CREs (up to 23) occurred following RH fluctuations of 5 to $15 \%$. Watering resulted in an immediate increase $(\leq 25 \%)$ followed by a rapid decrease in $\mathrm{RH}(\leq 32 \%)$ beginning 1 to $2 \mathrm{~h}$ later. In GH 2 and GH 11, 89 and 48\%, respectively, of the CREs occurred within $3 \mathrm{~h}$ following greenhouse watering. When greenhouse temperatures exceeded $25^{\circ} \mathrm{C}$ for 21 days in May (GH 2) and 19 days in March (GH 11), atmospheric conidial concentrations were reduced 80 and $75 \%$ from the previous months, respectively.
\end{abstract}

Additional keywords: powdery mildew

Poinsettias (Euphorbia pulcherrima Willd. ex Klotzsch) have a wholesale value in the United States of $\$ 212$ million, with California, Florida, Ohio, and Michigan leading production (19). Poinsettias are propagated by taking tip or terminal cuttings from the branches of vegetative stock plants and placing them in rooting medium (20). Primary propagators maintain stock plants all year for cutting production. Secondary propagators purchase cuttings for stock plant production from primary propagators beginning in early spring. Cuttings from these stock plants are sold in midsummer to growers who produce the flowering crop. Management of foliar diseases is a concern throughout all stages of poinsettia production. The primary foliar disease of poinsettia historically has been

Corresponding author: J. M. Byrne

E-mail: byrnejm@msu.edu

Current address of B. D. Shaw: Department of Plant Pathology, Cornell University, New York State Agricultural Experiment Station, Geneva 14456.

This study was supported by funding from the American Floral Endowment.

Accepted for publication 23 June 2000.

Publication no. D-2000-0817-02R

(C) 2000 The American Phytopathological Society leaf, stem, and bract blight caused by $\mathrm{Bo}$ trytis cinerea Pers.:Fr. (16).

Powdery mildew on poinsettias in the United States was first reported in 1990 (9) and was epidemic in Michigan in 1992. Although the disease is not common, it occurs yearly and is an economically significant problem, especially for poinsettia growers in the midwestern and northern United States (M. K. Hausbeck, unpublished data). In the absence of an observed teleomorph, the causal agent of this powdery mildew is referred to simply as Oidium sp. and is recognized by its production of conidia in chains on upright conidiophores characterized by an arched basal cell (6).

Signs of disease appear as small, white, talcum-like colonies on bract or leaf surfaces; colonies can coalesce to cause blighting. If colonies first develop on the undersides of leaves, the disease may go undetected until late in production when bracts become infected, making plants unsaleable. Although applications of appropriate fungicides to poinsettia bracts prevent further colony development, the fungal mycelium remains visible and is commercially unacceptable. Additionally, residue and phytotoxicity resulting from fungicide applications to the bracts may result in an unmarketable crop.

Scouting the poinsettia crop for early signs of the disease can ensure timely fun- gicide applications prior to bract coloration. However, frequent scouting is time consuming and difficult for large greenhouse operations that may have more than an acre of closely spaced poinsettias. Popular poinsettia cultivars are susceptible to powdery mildew (5); therefore, growers have relied on preventive applications of systemic fungicides prior to bract coloration to manage the disease. An improved understanding of the epidemiology of this pathogen could contribute to development of a disease management program that reduces unnecessary fungicide applications without increased risk of disease. Recent research conducted under controlled environmental conditions indicates that temperature influences conidial germination, haustorium formation, development of secondary germ tubes, and sporulation $(3,4)$. The objective of this study was to determine the role of environment in prompting atmospheric concentrations of Oidium sp. conidia in research greenhouses containing infected poinsettias. The influence of temperature on disease development was also of interest.

\section{MATERIALS AND METHODS}

Multistemmed, 8- to 10-week-old poinsettias with colored bracts, grown in 13.2cm-diameter plastic pots in commercial soilless potting mix composed of $40 \%$ perlite and $60 \%$ sphagnum peat moss, were obtained from a commercial Michigan greenhouse in November. A mixture of cultivars representing a range of disease susceptibility was used. Cultivars included Eckespoint Red Sails, Peace Jolly Red, Gross Supjibi Red, Gutbier V-14 Glory, Eckespoint Jingle Bells 3, Annette Hegg Hot Pink, Gutbier V-14 Pink, Eckespoint Pink Peppermint, Gutbier V-17 Angelika Marble, Annette Hegg Topwhite, Gutbier V-14 White, and Gutbier V-17 Angelika White. A random assortment of cultivars was spaced eight to nine pots per square meter on three benches in each of two glass research greenhouses located in the same complex, hereafter referred to as greenhouse $(\mathrm{GH}) 2(9$ by $8.5 \mathrm{~m})$ and $\mathrm{GH}$ 11 ( 5.5 by $8.8 \mathrm{~m}$ ). Ideally, this study would have been conducted in adjacent greenhouses; however, greenhouse availability was a constraint. Plants were hand watered as needed, with care taken to avoid wetting the foliage. Plants were fertilized during watering with 200 ppm of 15-5-25 (N-P-K) poinsettia fertilizer (Grace-Sierra Horti- 
cultural Products Company, Milpitas, CA) at 2- to 3-day intervals. The irrigation water $\mathrm{pH}$ was maintained at 5.8. Glasshouse temperatures were set for 21.1 to $22.0^{\circ} \mathrm{C}$ and vented when temperatures exceeded $26.0^{\circ} \mathrm{C}$. Temperature and relative humidity (RH) were monitored using a Neogen EnviroCaster (Neogen, Mason, MI) that recorded the environmental parameters every $15 \mathrm{~min}$ and calculated hourly averages. The number of days in each spore sampling week having one or more hourly average temperatures exceed 25.0 or $30.0^{\circ} \mathrm{C}$ was calculated. Light levels were natural photoperiods. When entering the greenhouses, personnel documented the date, time of day, and greenhouse activity performed, such as irrigation, vent opening, equipment maintenance, and cleaning of benches. Fungicides were not applied for the duration of the experiment.

In GH 2, inoculation occurred on 18 November by vigorously shaking mildewinfected plants with actively sporulating colonies above the healthy poinsettias. Colonies were observed on inoculated plants within 10 days. Although plants in GH 11 were not intentionally inoculated, colonies were first observed on 29 November. Both bracts and foliage were infected during the epidemic.

Concentrations of airborne conidia were monitored in each greenhouse using a 7day volumetric spore sampler (Burkard Mfg. Co. Ltd., Rickmansworth, Herfordshire, England) placed in the center of a bench from 5 December to 1 June and from 5 December to 17 July in GH 11 and GH 2, respectively. Observations were not continued for an additional season due to the time-consuming nature of this type of study. The spore sampler was operated at a flow rate of 10 liters/min and the orifice was set level with the top of the plant canopy and fixed in a direction perpendicular to the bench. Conidia were impacted onto tapes coated with an adhesive mixture of petroleum jelly and paraffin $(9: 1, \mathrm{wt} / \mathrm{wt})$ dissolved in sufficient toluene to give a

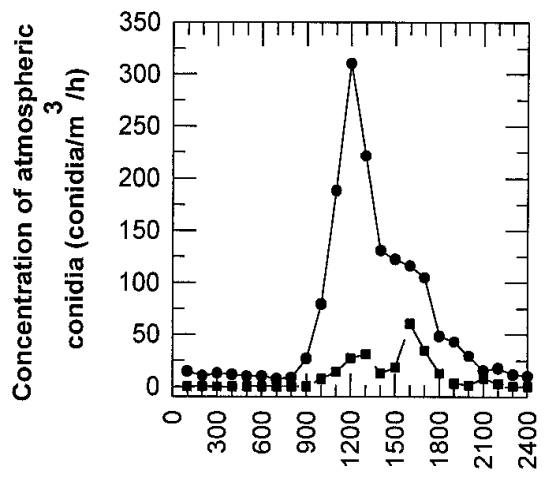

Time (h)

Fig. 1. Hourly average concentration of airborne conidia of Oidium sp. in research greenhouses $2(\bullet)$ and $11(\boldsymbol{\square})$ from 5 December to 1 June. thick, liquid consistency. Tapes were removed weekly, cut into 48-mm lengths, marked at 2-mm intervals with a razor blade to indicate hourly intervals, stained with aniline blue in lactic acid $(28 \mathrm{mg}$ of aniline blue, $20 \mathrm{ml}$ of distilled water, 10 $\mathrm{mg}$ of glycerol, and $10 \mathrm{ml}$ of $85 \%$ lactic acid, diluted with 5 drops to $25 \mathrm{ml}$ of distilled water), and mounted on glass slides beneath 22-by-50-mm coverslips. Under a compound microscope $(\times 100)$, conidia were identified as Oidium sp. based on conidium size, shape, color, surface texture, and translucence. The number of conidia sampled during each 1-h period were recorded. When conidial concentrations were exceptionally large $\left(>2,000 / \mathrm{m}^{3} / \mathrm{h}\right)$, a portion of the $2-\mathrm{mm}$ interval was counted and multiplied by the appropriate factor to provide an estimate of the concentrations for the 1-h period. Counts were converted to numbers of conidia per cubic meter of air sampled per hour.

From 23 January to $20 \mathrm{March}$, nine healthy, red-bracted poinsettias (cv. Freedom Red) grown as previously specified were placed in each greenhouse (three per each of three benches) for 7-day periods, after which they were removed and incubated in a nearby greenhouse under similar environmental conditions. The number of days to the appearance of the first visible colony following the exposure period was recorded for each plant. Once plants developed visible colonies, they were immediately removed to minimize contamination of the greenhouse atmosphere and nearby poinsettias. Because of limited numbers of poinsettias available, three plants were used each week (one per bench) from 3 April to 3 July for GH 2.

\section{RESULTS}

Atmospheric conidial concentrations. When averaged over the observation period (5 December to 1 June), atmospheric conidial concentrations in GH 2 were greatest during 1000 to 1800 hours, with a peak ( 325 conidia $/ \mathrm{m}^{3} / \mathrm{h}$ ) occurring at 1200 hours (Fig. 1). Overall, atmospheric conidial concentrations were much lower in GH 11 compared with GH 2, with peak concentrations occurring at 1300 hours (65 conidia $/ \mathrm{m}^{3} / \mathrm{h}$ ) and 1600 hours (75 con$\mathrm{idia} / \mathrm{m}^{3} / \mathrm{h}$ ) (Fig. 1). During the course of this study, large numbers of conidia were sampled $\left(\geq 100 / \mathrm{m}^{3}\right)$ within 1 -h periods, indicating conidial release events (CREs). A total of 134 and 50 CREs occurred in GH 2 and GH 11, respectively, with maximum CREs occurring at 1100 and 1200 hours (GH 2) and 1300 hours (GH 11) (data not shown). CREs were negligible ( $\leq 1)$ from 2000 to 0800 hours in both greenhouses.

RH fluctuations. Fluctuations in $\mathrm{RH}$ (either positive or negative) prompted CREs (Fig. 2). In both greenhouses, the highest number of CREs (up to 23) occurred following $\mathrm{RH}$ fluctuations (either positive or negative) of 5 to $15 \%$ (Table 1), although fluctuations in $\mathrm{RH}$ were as high as $32 \%(\mathrm{GH} \mathrm{2})$ and $27 \%(\mathrm{GH} \mathrm{11).} \mathrm{One}$ CRE occurred in GH 2 without a fluctuation in $\mathrm{RH}$ in the $3 \mathrm{~h}$ preceding the event.

Watering resulted in an immediate increase $(\leq 25 \%)$ followed by a rapid decrease $(\leq 32 \%)$ in $\mathrm{RH}$ beginning 1 to $2 \mathrm{~h}$ later. In GH 2, $89 \%$ of the 134 CREs occurred within $3 \mathrm{~h}$ following plant watering (data not shown). In GH 11, $48 \%$ of the 50 CREs were observed within $3 \mathrm{~h}$ of watering (data not shown). Some CREs were observed that were not associated with watering. In GH 2, 11 of these 15 CREs were associated with a fluctuation of 5 to $23 \%$ in $\mathrm{RH}$ within $3 \mathrm{~h}$ of the CRE onset (data not shown). In GH 11, 80\% of the 25 CREs not associated with watering were preceded by a natural RH fluctuation ranging from 5 to $28 \%$ within $3 \mathrm{~h}$ of the CRE onset (data not shown).

The largest CRE in each greenhouse (estimated at 8,500 conidia $/ \mathrm{m}^{3} / \mathrm{h}$ ) was preceded by a $10 \%$ decrease in $\mathrm{RH}$; in $\mathrm{GH} 11$, a $10.0^{\circ} \mathrm{C}$ decrease in temperature also occurred. In GH 2, CREs lasting 10 or more hours occurred eight times during the observation period. On 29 March, the CRE began at 1200 hours, lasted $55 \mathrm{~h}$, and released a total of 27,625 conidia $/ \mathrm{m}^{3}$ (Fig. 3). The onset of this event was associated with a watering event and an $8 \%$ increase in RH. Elevated peaks within this extended CRE period were associated with fluctuations in RH. Similar CREs did not occur in GH 11.

During the study, vents in GH 2 were opened on 50 days. On 34 of these days, plants were watered as the vents opened, prompting CREs within $3 \mathrm{~h}$ on 11 occasions. When venting occurred without watering, CREs were observed $14 \%$ of the time. Greenhouse 11 was vented 58 times during the course of this study. On three of these days, CREs occurred within $3 \mathrm{~h}$ of greenhouse venting or plant watering while venting.

Temperature. Although this study was conducted in greenhouses of similar size, construction, and orientation located in the same complex, the environmental conditions varied between greenhouses. In GH 2 , temperatures did not routinely exceed $25.0^{\circ} \mathrm{C}$ during the first six weeks (23 January to 6 March) of the study (Fig. 4). Thereafter, temperatures exceeded $25.0^{\circ} \mathrm{C}$ on three to six days during each week. However, during weeks 19 to 24 (29 May to $10 \mathrm{July}$ ), temperatures exceeded $30.0^{\circ} \mathrm{C}$ on one to seven days per week and corresponded to the lowest conidial concentrations occurring in this study $(<1,200$ $\mathrm{m}^{3}$ /week) (Fig. 4).

In GH 11, temperatures exceeded $25.0^{\circ} \mathrm{C}$ on one to five days per week during the study (Fig. 5). Temperatures exceeding $30.0^{\circ} \mathrm{C}$ were not observed until week 7 (6 to 13 March). On March 11, the temperature reached $39.1^{\circ} \mathrm{C}$ and prompted several 
CREs $\left(\leq 8,500\right.$ conidia $\left./ \mathrm{m}^{3} / \mathrm{h}\right)$ (data not shown). Total conidial concentrations for weeks 1 to 7 (23 January to 13 March) were 31,653 conidia $/ \mathrm{m}^{3}$. Following the extreme high temperature occurring in week 7, CREs were reduced for the duration of the study. Total conidial concentrations for weeks 8 (13 to 20 March) to 18 (22 to 29 May) were $5,832 / \mathrm{m}^{3}$ (Fig. 5). During week 15 (1 to 8 May), temperatures exceeded $30.0^{\circ} \mathrm{C}$ each day of the week. Subsequently, atmospheric conidial concentrations were not detected for the remainder of the study.

Disease development. Disease developed on plants placed in GH 2 from week 1 to week 20 (23 January to 12 June). Time
Table 1. Number of conidial release events associated with relative humidity (RH) fluctuations (positive or negative) occurring from 5 December to 1 June in greenhouse (GH) 11 and 5 December to 17 July in GH 2

\begin{tabular}{lrrrrr}
\hline & \multicolumn{4}{c}{ Number of conidial release events } \\
\cline { 2 - 3 } \cline { 5 - 6 } RH fluctuation (\%) & + & - & & \multicolumn{3}{c}{ GH 11 } \\
\cline { 2 - 3 } \cline { 5 - 6 } $1-4$ & 1 & 0 & & 0 & - \\
$5-10$ & 7 & 8 & & 2 & 0 \\
$11-15$ & 21 & 18 & & 4 & 9 \\
$16-20$ & 23 & 15 & & 10 & 3 \\
$21-25$ & 9 & 9 & & 6 & 2 \\
$26-30$ & 9 & 8 & & 2 & 2 \\
$>30$ & 2 & 2 & & 0 & 2 \\
\hline
\end{tabular}
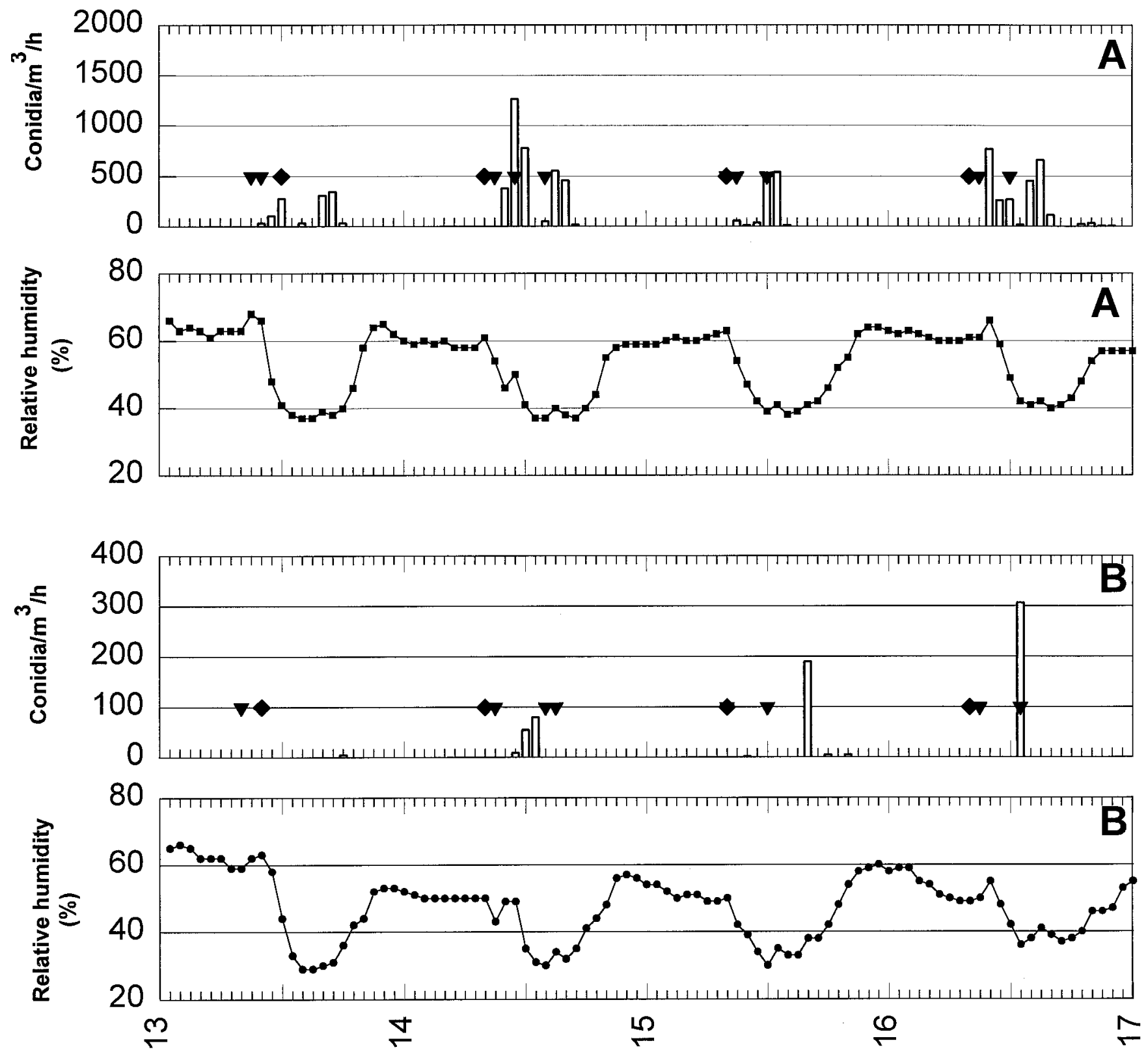

Time

Fig. 2. Association of greenhouse activity, including watering $(\boldsymbol{\nabla})$ and venting $(\bullet)$, and fluctuation of relative humidity with concentration of airborne conidia of Oidium sp. in research greenhouses (A) 2 and (B) 11 during 13 through 16 March. 

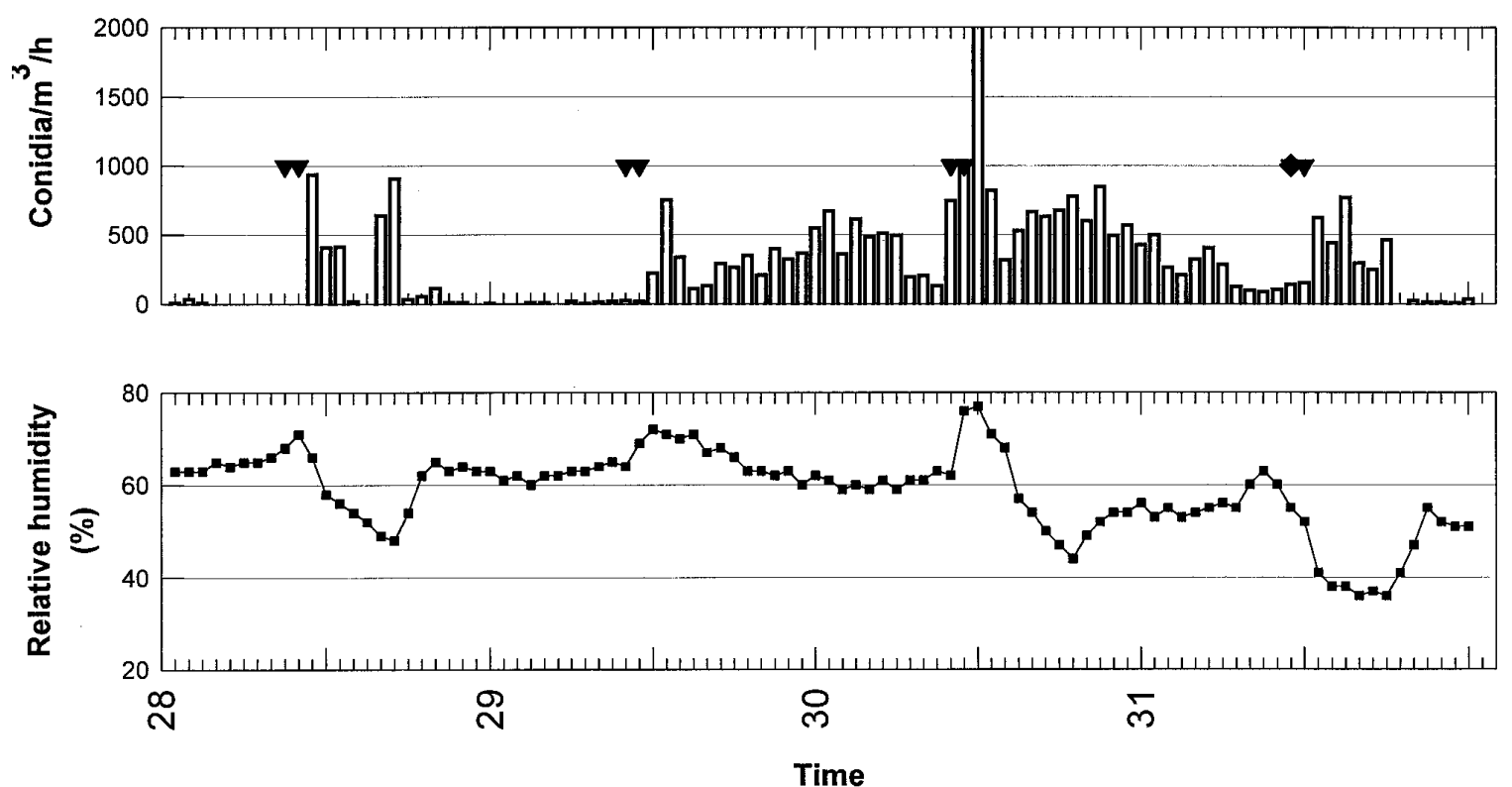

Fig. 3. Extended conidial release event period and associated greenhouse activity, including watering $(\boldsymbol{\nabla})$ and venting $(\diamond)$, and fluctuations of relative humidity in greenhouse 2 during 28 through 31 March.
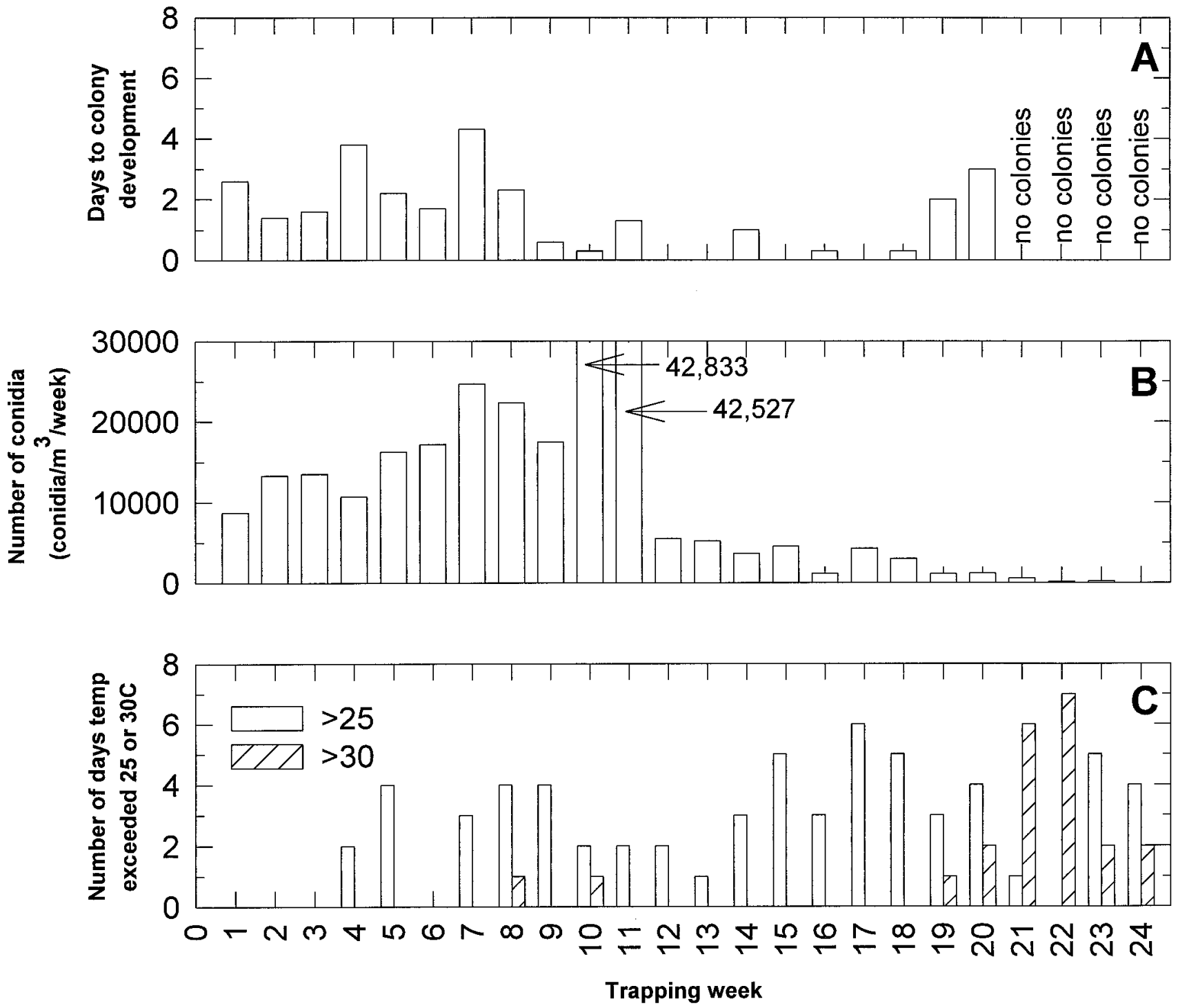

Fig. 4. (A) Days to colony development on poinsettias following exposure to atmospheric conidial concentrations, (B) total number of conidia released during the trap week, and (C) number of days the average hourly temperatures exceeded 25 and $30^{\circ} \mathrm{C}$ in research greenhouse 2 during 23 January to 10 July. 
to colony development ranged from 0 (colonies developed during the exposure week) to 4.3 days after the exposure period (Fig. 4). Atmospheric conidial concentrations during this period ranged from 1,185 to 42,833 conidia $/ \mathrm{m}^{3} /$ week. No colonies developed on plants placed in GH 2 during weeks 21 to 24 (12 June to 10 July). During this period, fewer than 600 con$\mathrm{idia} / \mathrm{m}^{3} /$ week were released.

When plants were placed in GH 11 during weeks 1 to 6 (23 January to 6 March) and week 9 (20 to 27 March), colonies developed within an average of 3 to 7 days after the exposure period (Fig. 5). During week 7 (6 to $13 \mathrm{March}$ ), when temperatures reached $39.1^{\circ} \mathrm{C}, 19,502$ conidia $/ \mathrm{m}^{3}$ were released, although plants exposed during this time did not develop colonies. During week 9 (20 to 27 March), 2,322 conidia $/ \mathrm{m}^{3}$ were released and exposed plants developed colonies.

\section{DISCUSSION}

Concentrations of airborne conidia of Oidium sp. were present in the greenhouses throughout the monitored period. The production and release of conidia of many powdery mildew species is diurnal and we observed conidial release largely between 1000 and 1400 hours. The periodicity of powdery mildews which form conidia in chains is determined by the final stage of sporulation, when the abstriction of the conidium from the germ cell of the conidiophore occurs (2). This maturation stage is photosensitive, proceeding faster in light than in dark; therefore, conidia produced at night remain immature and are released once exposed to light (8). Observational field studies of powdery mildew on grapes (24), rubber (10), cherry (12), apple (22), barley (13), and tobacco (7) have also documented diurnal conidial release patterns. Release patterns are also influenced by wind speed, rainfall, fungicide applications, temperature, RH, and solar radiation, which also tend to follow diurnal patterns $(23,24)$.

In our study, a primary factor influencing the occurrence of CREs was fluctuation of RH, often caused by watering. The association of conidial release in response to RH fluctuation has been similarly observed with other powdery mildew species including Sphaerotheca pannosa, Erysiphe pisi, and E. graminis (1). Conidial release by $S$. pannosa occurs in response to abrupt decreases in $\mathrm{RH}$, whereas release by $E$. graminis occurs in response to increasing RH. Butt (2) proposed that the variation in sensitivity to RH may be due to differences in the hygroscopic properties of the spore wall. E. pisi does not discharge conidia in response to $\mathrm{RH}$ fluctuation alone; conidial liberation occurs when $\mathrm{RH}$ change is accompanied by exposure to light and in-
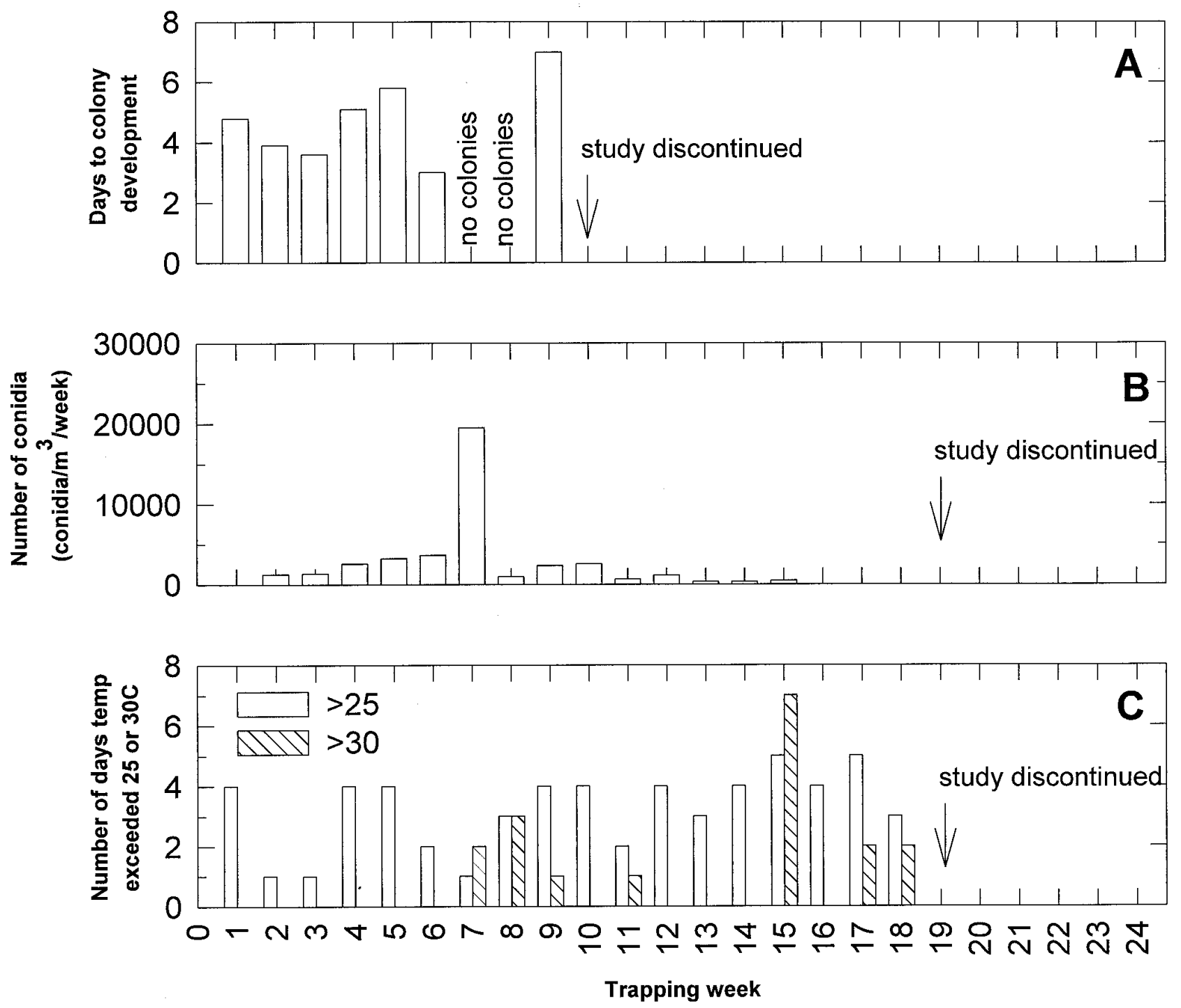

Fig. 5. (A) Days to colony development on poinsettias following exposure to atmospheric conidial concentrations, (B) total number of conidia released during the trap week, and $(\mathbf{C})$ number of days the average hourly temperatures exceeded 25 and $30^{\circ} \mathrm{C}$ in research greenhouse 11 during 23 January through 10 July. 
creasing temperature. In our study, CREs occurred in response to both positive and negative changes in RH. Although many CREs occurred in conjunction with temperature changes, it was not required for conidial release.

Although we have found an association between $\mathrm{RH}$ fluctuations and conidial release in Oidium sp. of poinsettia, the mechanism of release is not known. Both passive and active liberation mechanisms have been proposed for powdery mildew species (18). Mechanical disruption (13), wind speed (11), and humidity (1) or temperature changes have been associated with high conidial releases of powdery mildews. In field situations, wind plays a significant role in the release and conidial dispersal of many powdery mildew species, either directly or as a result of leaf movement dislodging conidia $(10,14,23)$. In the greenhouse, significant air movement is limited to that caused by cooling fans or open vents. An alternative method of dispersal is hygroscopic twisting in response to changing RH. This twisting causes movement capable of dislodging spores of Phytophthora and Peronospora spp. (18). However, Jarvis (15) concluded that hygroscopic movements loosen spores of $B$. cinerea for subsequent or rain-splash dispersal. Adams (1) proposed that a change from high to low RH creates an electrical charge with sufficient voltage to remove powdery mildew conidia from conidiophores.

Optimum temperatures reported for powdery mildews $\left(21.0^{\circ} \mathrm{C}\right)$ are generally lower than those for other plant pathogens (2). Studies comparing effects of temperature on Oidium sp. on poinsettia found conidial germination was significantly reduced at $30^{\circ} \mathrm{C}(<64 \%)$ versus $20.0^{\circ} \mathrm{C}$ $(\geq 80 \%)$. At $30.0^{\circ} \mathrm{C}$, formation of secondary germ tubes was significantly limited $(<1 \%)$ compared with $20^{\circ} \mathrm{C}(\geq 53 \%)$. Less than $4 \%$ of germinated conidia formed haustoria at $30.0^{\circ} \mathrm{C}$, compared with $>53 \%$ of those at $20.0^{\circ} \mathrm{C}$.

In our study, temperature exceeded $25.0^{\circ} \mathrm{C}$ for 21 days in May in $\mathrm{GH} 2$ and the atmospheric conidial concentration was $20 \%$ of that occurring in April, when only 9 days exceeded $25.0^{\circ} \mathrm{C}$. Similarly, in GH 11 , when the number of days the temperature exceeded $25.0^{\circ} \mathrm{C}$ increased from 9 in February to 19 in March, the atmospheric conidial concentration was reduced by $75 \%$. As a result, the powdery mildew epidemics in the greenhouses naturally lost intensity in March (GH 11) and June (GH 2). For the last 5 weeks of the study, temperatures in $\mathrm{GH} 2$ exceeded $30.0^{\circ} \mathrm{C}$ at least 2 days per week. At the conclusion of the study in GH 2, colonies were no longer developing on exposed plants and atmospheric conidial concentrations were declining, such that $<100$ conidia $/ \mathrm{m}^{3}$ were released in the final week of monitoring. In GH 11, following the high temperature of $39.1^{\circ} \mathrm{C}$ in March (week 7), atmospheric conidial concentrations were reduced $\left(\leq 833\right.$ conidia $\left./ \mathrm{m}^{3} / \mathrm{h}\right)$. Colonies did not develop on plants exposed during weeks 7 and 8 , when temperatures exceeded $30.0^{\circ} \mathrm{C}$ on two to three days per week. Similar temperature effects have been observed with other powdery mildew species. The maximum temperature for germination and appressorium formation of $O$. begoniae is also $30.0^{\circ} \mathrm{C}$; colonies on mature leaves were eradicated by exposure to $32.0^{\circ} \mathrm{C}$ for 3 days (21).

Kim et al. (17) observed that plants with active powdery mildew colonies, grown in a greenhouse throughout the summer and exposed to high temperatures and solar radiation, showed no signs of infection for a period of time. In two commercial greenhouses in Michigan where powdery mildew was detected in July or August, colonies were found only on the abaxial sides of the bottom leaves where temperatures would be cooler as a result of canopy shade and close proximity to the moist surface of the growing medium (M. K. Hausbeck, personal observation). Because of the colony formation on leaf undersurfaces, without thorough and frequent scouting, low levels of disease would thus escape undetected. However, as the season progresses and temperatures decrease, conditions will be more favorable for further colony development, with associated high and frequent CREs prompting rapid onset of an epidemic. At this point, colonies would likely be evident on the adaxial surface of upper leaves or bracts and widespread enough to be noticed by growers. Michigan conditions at this point would not naturally exceed $25.0^{\circ} \mathrm{C}$; therefore, the epidemic would proceed unhindered and result in entire poinsettia crops being unsaleable. This has occurred many times in Michigan in the last several years.

The ability of powdery mildew to become epidemic seemingly at a time when poinsettias have colored bracts and are especially vulnerable to phytotoxicity and residues from fungicides has made disease management difficult. Although thorough scouting for signs of infection is optimum for prompting fungicide sprays, many growers do not have the necessary personnel to accomplish the task. Rather, some growers apply preventive fungicides during the entire production cycle until just prior to bract coloration. Results from this study may be helpful in the eventual development of a disease management strategy that utilizes environmental conditions to prompt fungicide sprays.

\section{LITERATURE CITED}

1. Adams, G. C., Jr., Gotwald, T. R., and Leach, C. M. 1986. Environmental factors initiating liberation of conidia of powdery mildews. Phytopathology 76:1239-1245.

2. Butt, D. J. 1978. Epidemiology of powdery mildews. Pages 51-81 in: The Powdery Mildews. D. M. Spencer, ed. Academic Press,
New York.

3. Byrne, J. M., and Hausbeck, M. K. 1998. Influence of temperature and relative humidity on infection processes and sporulation on Oidium sp. on poinsettia foliage. (Abstr.) Phytopathology 88:S134.

4. Byrne, J. M., and Hausbeck, M. K. 1999. The effect of temperature on sporulation of Oidum sp. on poinsettia foliage. (Abstr.) Phytopathology 89:S10.

5. Celio, G. J., and Hausbeck, M. K. 1997. Evaluation of poinsettia cultivars for susceptibility to powdery mildew. HortScience 32:259-261.

6. Celio, G. J., and Hausbeck, M. K. 1998. Conidial germination, infection structure formation, and early colony development of powdery mildew on poinsettia. Phytopathology 88:105-113.

7. Cole, J. S. 1966. Powdery mildew of tobacco (Erysiphe cichoracearum DC) IV. Conidial content of the air within infected crops. Ann. Appl. Biol. 57:445-450.

8. Cole, J. S., and Fernandes, D. L. 1970. Effects of light, temperature and humidity on sporulation of Erysiphe cichoracearum on tobacco. Trans. Br. Mycol. Soc. 55:345-353.

9. Daughtrey, M. L., and Hall, J. 1992. Powdery mildew: A new threat to your poinsettia crop. Grow. Talks Sept.:23-31.

10. Fernando, T. M. 1971. Oidium leaf disease; the effect of environment and control measures on incidence of disease and atmospheric spore concentration. [Hevea brasiliensis]. Q. J. Rubber Res. Inst. Ceylon 48:100-111.

11. Frinking, H. D. 1977. Research on wind dispersion of rose-mildew spores (Sphaerotheca pannosa) in field, glasshouse and climate room. Grava 16:155-158.

12. Grove, G. G. 1991. Powdery mildew of sweet cherry: influence of temperature and wetness duration on release and germination of ascospores of Podosphaera clandestina. Phytopathology 81:1271-1275.

13. Hammett, K. R. W., and Manners, J. G. 1971. Conidium liberation in Erysiphe graminis. I. Visual and statistical analysis of spore trap records. Trans. Br. Mycol. Soc. 56:387-401.

14. Hammett, K. R. W., and Manners, J. G. 1974 Conidium liberation in Erysiphe graminis. III. Wind tunnel studies. [Wheat]. Trans. Br. Mycol. Soc. 62:267-282.

15. Jarvis, W. R. 1962. The dispersal of spores of Botrytis cinerea Fr. in a raspberry plantation. Trans. Br. Mycol. Soc. 45:549-559.

16. Jones, R. K., and Strider, D. L. 1985. Bedding plants. Pages 409-422 in: Diseases of Floral Crops, Vol. 1. D. L. Strider, ed. Praeger Publishers, New York.

17. Kim, S. H., and Olson, T. N. 1995. Recurrence of powdery mildew on over-summered asymptomatic poinsettias. (Abstr.) Phytopathology 85:1171.

18. Lacey, J. 1996. Spore dispersal-Its role in ecology and disease: The British contribution to fungal aerobiology. Mycol. Res. 100:641660.

19. National Agricultural Statistics Service. 1999. Floriculture crops, 1998 summary. Agricultural Statistics Board, U. S. Dep. Agric. Washington, DC.

20. Nau, J. 1998. Euphorbia pulcherrima. Pages 482-509 in: Ball Red Book, 16th ed. V. Ball, ed. Ball Publishing, Batavia, IL.

21. Quinn, J. A., and Powell, C. C., Jr. 1982. Effects of temperature, light, and relative humidity on powdery mildew of begonia Oidium begoniae on Begonia x hiemalis. Phytopathology 72:480-484.

22. Sutton, T. B., and Jones, A. L. 1979. Analysis of factors affecting dispersal of apple powdery mildew caused by Podosphaera leuco- 
tricha conidia. Phytopathology 69:380-383.

23. Willocquet, L., Berud, F., Raoux, L., and Clerjeau, M. 1998. Effects of wind, relative humidity, leaf movement and colony age on dispersal of conidia of Uncinula necator, causal agent of grape powdery mildew. Plant Pathol. 47:234-242.

24. Willocquet, L., and Clerjeau, M. 1998. An analysis of the effects of environmental factors on conidial dispersal of Uncinula necato (grape powdery mildew) in vineyards. Plant Pathol. 47:227-233. 